\title{
Ethical Implications For Attorneys Involved In Extraterritorial Application Of The Civil Rights Acts
}

Howard E. McNier, General Counsel, Team-Slugga Co. Ltd., Bangkok, Thailand

\begin{abstract}
Globalization of business has increasingly involved American attorneys in an ethical dilemma which is not just academic, but may result in disciplinary action against the attorney. What is counsel to do when it is discovered that overseas employment practices (legal in the foreign country) violate American law? May counsel, citing current case law, ethically advise management that discharge of a troublesome employee may be effected "legally" by simply transferring the employee overseas, then firing her? These ethical issues can be put in sharp focus by reviewing a provision of the 1991 Civil Rights Act (CRA) that extends application of the 1964 CRA to cover American citizens working overseas for American owned or controlled firms. Expansive interpretation of this by the Equal Employment Opportunity Commission (EEOC) has ensnarled over 21,000 overseas businesses with the threat of being sued, in the United States, for employment practices committed outside of the United States.
\end{abstract}

Keywords: Legal Ethics; Civil Rights Act; Extraterritorial Application

\section{INTRODUCTION: A Brief Review Of The Civil Rights Act, "Title VII"}

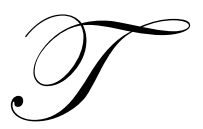

o create equal employment opportunity and to eliminate barriers favoring white males employees over others, the United States Congress passed the Civil Rights Act of 1964, commonly called "Title VII"i. The law gave birth to a cause of action against U. S. employers for employment discrimination based upon race, sex, religion, national origin, or color. Over time, a complicated body of law has grown defining exactly what constitutes illegal as opposed to legal (bona fide occupational qualifications) employment discrimination. Too, over time, employers' anxiety over large jury awards to plaintiffs in CRA cases has increased.

Until 1991, overseas operations of U. S. firms had little to fear in this regard. Rumors spread that clever counsel could easily circumnavigate "Title VII" (e.g. simply transfer a troublesome employee, who was felt to be likely to sue, overseas, then fire her). This ended quite suddenly in 1991 when Congress reacted angrily to a series of Supreme Court decisions that many commentators felt decimated Title VII. ${ }^{\text {ii }}$

\section{EXTRATERRITORIAL APPLICATION OF THE CRA}

When Congress passed the CRA, no mention was made concerning any application outside of the fifty states. Questions soon arose about apparent discriminatory acts committed by U. S. employers against U. S. citizens working in foreign countries.

Courts, facing lawsuits filed on behalf or these workers, sometimes applied Title VII extraterritorially based upon a negative inference that, since one provision of Title VII precludes coverage specifically to aliens working outside of the U. S., then U. S. citizens must be covered. The EEOC agreed with this and, in 1988, published a regulation stating that Title VII applied to U. S. citizens working overseas. ${ }^{\text {iii }}$ 
Most courts, however, followed the lead of Bourselan v. Arabian American Oil Company (ARAMCO), 653 F. Supp. 629, Texas (1987). This case denied extraterritorial application, citing: (a) no specific language in the law extending coverage, and (b) concern over strained foreign relations if the U. S. were to regulate actions taking place in foreign countries. ${ }^{\text {iv }}$

The Supreme Court, in 1991, agreed in its ARAMCO appeal decision citing additionally that Congress had explicitly extended coverage of the Age Discrimination In Employment Act to U. S. citizens working overseas. Thus, if Congress did not specifically provide for extraterritorial application of the CRA, it would not be allowed. ${ }^{\mathrm{v}}$

The date of the Supreme Court decision was March 26, 1991--the very same date Congress was ready to vote on massive revisions to the 1964 CRA. At the last minute, a provision (Sect. 109) was added to the legislation (soon to be called "The Civil Rights Act of 1991" due to its comprehensive nature) entitled "Protection of Extraterritorial Employment". With almost no debate (thus no later guidance for courts) Section 109 was passed. ${ }^{\text {vi }}$

Thus, Section 109 of the Civil Rights Act of 1991 (42 U.S.C. 1211, 2000e) amended Title VII and the Americans With Disabilities Act as follows:

1. "Employee" includes, with respect to employment in a foreign country ... any individual who is a citizen of the United States;

2. Title VII and the ADA will cover discrimination against United States citizens abroad if engaged in by an American employer or by a foreign corporation controlled by an American employer;

3. Factors to consider in determining whether an American employer controls a foreign corporation, include:

a. the interrelationship of operations;

b. common management;

c. centralized control of labor relations; and

d. common ownership or control of the two entities.

4. A defense to violation of the law exists if compliance with U.S. law would cause the subject employer to "violate the law of the foreign country" in which the subject workplace is located. ${ }^{\text {vii }}$

\section{THE VAST IMPACT OF EXTRATERRITORIAL APPLICATION OF THE U.S. CIVIL RIGHTS LAW}

Since congress hardly debated the inclusion of Section 109, its intent (so-called "legislative history") is not clear in several crucial areas. The EEOC, as the daily enforcing agency for civil rights laws, (now backed with more power than it had in respect to the 1964 law) stepped in to fill the gaps.

\section{JUST HOW MANY “FOREIGN WORKPLACES” ARE WE TALKING ABOUT}

Congressional resources (137 Cong. Rec. H3922, H3934) declared that immediately upon ratification of the new law (1991), an estimated 2,000 U.S. companies operating 21,000 overseas units in 121 countries were covered. Today, Wal-Mart alone has over 2,200 stores outside of the U. S. and that looks meager compared to McDonald's 18,000 restaurants overseas!

\section{IGNORANCE OF THE LAW IS NO EXCUSE}

In the U.S. system of law, ignorance of the law is not a defense.

Worse still for many firms, some aspects of U.S. civil rights law can be violated WITHOUT INTENT! For instance, so-called "disparate impact" discrimination (in which, for example, an employer might mandate that prospective employees in a security guard position be over 6' tall) is illegal. U.S. courts have said repeatedly that such a height requirement which disqualifies large portions of certain protected groups (e.g. women), requires no intent on the part of the employer for a finding of guilt to arise. .iii $^{2}$ 


\section{AN ILLUSTRATION OF THE COMPLEXITY OF THE U.S. CIVIL RIGHTS ACTS}

In the United States, sex discrimination has been prohibited since Congress passed Title VII of the Civil Rights Act of 1964. Title VII states that "I shall be unlawful employment practice for an employer ... to fail or refuse to hire or to discharge any individual with respect to his compensation, terms, conditions, or privileges of employment, because of such individual's ... sex..."

As the role and number of women in the workforce enlarged throughout the 1970's ever increasing voices called for women to be protected at work from physical sexual conduct (unwanted hugs, pinches, etc.), visual sexual insults (pictures of scantily-clad or nude women at work locations) and oral abuse (sex jokes and sex comments). Legally these three types of sexual harassment are called:

1. Quid Pro Quo -- sexual compliance is a prerequisite for pay, promotion, or some other employment opportunity;

2. Hostile Work Environment -- workplace conduct of a sexual nature that is severe enough to alter the conditions of the victim's employment and creates an abusive work environment; and

3. Third Party -- sexual harassment perpetrated by a customer, client, vendor, or other non-employee.

Finally, in 1986, the U.S. Supreme Court affirmed sexual harassment as a form of sex discrimination prohibited by Title VII. This case, Meritor Savings Bank v. Vinson, 40 FEP 1822, (1986), held that the definition of sexual harassment in the United States is: Unwelcome sexual advances, requests for sexual favors, and other verbal or physical conduct of a sexual nature constitute sexual harassment when:

1. Submission to such conduct is made either explicitly or implicitly a term or condition of the individual's employment;

2. Submission or rejection of such conduct by an individual is used as the basis for employment decisions affecting such individual; or

3. Such conduct has the purpose or effect of unreasonably interfering with an individual's work performance or creating an intimidating, hostile, or offensive work environment. ${ }^{\text {ix }}$

\section{SPECIAL ISSUES WITH EXTRATERRITORIAL ENFORCEMENT}

\section{A. What Constitutes An American Employer?}

Neither Section 109, nor any legislative history from Congress, provides a definition or determinative test for what is an American Employer. So, the EEOC in Enforcement Guidance on Application of Title VII and ADA to American Firms Overseas, declared that it would consider a firm operating overseas to be American if the firm has SUBSTANTIAL CONTACTS with the U. S. These include:

1. The nationality and location of top management;

2. The nationality of dominant shareholders; and

3. The location of the firm's home office. ${ }^{\mathrm{x}}$

\section{B. What Constitutes An American Controlled Foreign Employer?}

In addition to covering so-called American Employers overseas, Extraterritorial Application also applies to foreign firms that are American controlled. Stated differently, if a U. S. employer controls a corporation which is incorporated overseas, American courts (where, of course, plaintiffs would file their suits) will presume that any practice prohibited by Title VII and the ADA which is engaged in by the foreign-incorporated firm, has actually been done by a U. S. employer.

Clearly this provision is aimed at multinational firms operating overseas via subsidiaries or affiliates. Liability, thus, is imputed to the U. S. parent. Section 109 specifies four criteria for determining if a foreign company is, in fact, American controlled: 
1. Common management, especially top management;

2. Centralized control over labor relations;

3. Common ownership or financial control; and

4. Interrelationship of operation. ${ }^{\mathrm{xi}}$

\section{Defenses To Extraterritorial Application Of The Civil Rights Acts}

The Civil Rights Act of 1991 provides a very narrow range of defenses an American or American-controlled firm can raise to avoid extraterritorial application of the CRA's.

\section{Compliance With Foreign Laws}

Section 109 contains an exception to the normal civil rights rules and allows what would normally be illegal discrimination where it is necessary to comply with local country laws (NOT customs). But what is a "foreign law"?

\section{Ethical Or Cultural Relativism Vs. Law}

Business practices in many foreign countries are regulated, formally or informally, by what are perceived in the foreign country to be ethical or cultural norms. A simple example would be restrictions on women being allowed to work in many Muslim countries. Types of these ethical or cultural norms are:

a. Masculine/Feminine-based cultures. -- Masculine-based cultures are thought of as power and/or money dominated, thus less inclined to follow ethics rules, Whereas the feminine-based cultures put more stock in relationships, thus ethics in working conditions, etc. would be favored.

b. Tolerance of Uncertainty -- The level of uncertainty that is tolerated or desirability of taking risks (seen as dominant in the United States) is felt to thwart ethics policies as strict rules throttle individual initiative.

c. View of Power -- As seen in the recent political upheaval in Thailand, where gross disparities in power/wealth are assumed to be natural, ethical values will vary greatly from places like the U.S. where we are all "created equal". The former Prime Minister of Thailand started as a policeman and now is a billionaire in a country where the average annual wage for a family of four is less than US\$1,000, yet he gets ninety percent of the poor vote.

d. Type of Market a Business is in -- "Perfect Market" businesses (those in which freedom of entry and multiple competitors keep prices and profit margins low) tend to have a cut-throat atmosphere, thus ethical rules are difficult to enforce. In "Imperfect Markets" (large companies dominate and have dominated for many years), competition is not rough, thus there is more room for ethics to flourish.

The Foreign Laws Defense states that it is NOT unlawful for an overseas employer to take otherwise prohibited action if compliance with Title VII or the ADA in the foreign country would cause the overseas employer to violate the LAW of the country in which the firm is doing business. For the Defense to apply, the EMPLOYER MUST PROVE:

1. The action is taken in respect to an American citizen working in a foreign country; and

2. Compliance with Title VII WILL (NOT might) cause the employer to violate a local law. ${ }^{\text {ii }}$

Number 2 is the difficult area. What is a LAW? In Mahoney v. RFE/RL, Inc., 818 F. Supp. 1 (D.D.C. 1992) an American employer terminated the employment of a U.S. citizen working in Germany because of a union contract which mandated that nobody over sixty-five could work for the company. The U. S. court held that the discharge was illegal. The union contract, the court stated, was not a law, even if that contract could be enforced by courts in the foreign country. To allow the employer to have a defense to the American CRA by simply agreeing to a private union contract in a foreign country could not be allowed. xiii $^{2}$

One point the court made is especially worthy of ethical note: If, the court said, it had held otherwise, a foreign-based firm could simply negotiate provisions into union agreements to abrogate U.S. law. ${ }^{\text {xiv }}$ The company responded that the German labor court had upheld the contract and that the two decisions put the firm in a no-win 
position. The EEOC, however, adopted the court's point of view in its guidelines.

Of equal controversy is the issue of what is a "foreign law" in some countries where law is embodied in religion or patterns of life unchallenged for centuries, but not explicitly stated in a formal law. A simple example arose in Fernandez v. Wynn Oil Co., 653 F.2d 1273, $\left(9^{\text {th }}\right.$ Cir. 1981) which held the prejudices held by South American clients in which they refused to have business negotiations with a woman, would not rise to a BFOQ defense if the company refused a woman's application for a job. ${ }^{\mathrm{xV}}$

Relying, then, upon this case, the EEOC guidelines hold that an American or "American controlled" employer cannot cite cultural factors as rising to a "foreign law" defense to extraterritorial application of the U.S. law. (See also Abrams v. Baylor College of Medicine, 581 F.Supp. 1570 \{S.D. Tex. 1984\}, finding no BFOQ when the University rejected a Jewish applicant for a position in Saudi Arabia after conversations with Saudi officials made it clear that "Saudis did not want Jews in their country." ${ }^{\mathrm{xvi}}$

Another controversy arose concerning business in Japan. Japan's civil code is based upon that of France, while its constitution is based upon the United States model Thousands of years of custom however, preceded either the civil code or the constitution and regulated strictly the rules of social and business conduct. Called"giri", anyone visiting Japan sees it almost at once. The level to which one bows in greeting a boss vs. a co-worker (one bows much lower, thus offering one's neck to the Samurai sword, to a boss than to a co-worker) is all tied to "giri" yet one cannot find these traditions embedded in the civil code or constitution. ${ }^{\text {xvii }}$ Needless to say, then, the EEOC has held that obeying "giri" is not a Title VII defense.

And last, in a context in which a country's religion may make certain conduct (e.g. a married man having dinner with a single woman in a hotel restaurant) not only unacceptable, but subject to serious physical consequences, the EEOC has maintained its position. Thus, in an Islamic country, such as Egypt, Morocco, or Tunisia, which base their legal systems on the French model, but in which the Koran is deeply ingrained in daily life, an American or "American controlled" firm could not base a legal defense on adherence to traditional Muslim law. ${ }^{\text {xviii }}$

\section{Three Recent Court Cases}

Three recent court cases are worthy of note. In Denty v. SmithKline Beecham Corp., 109 F.3d 147 (3d Cir. 1997), Mr. Denty, a U.S citizen, applied for a position with his employer's home office in England. At the time of the application and at the time Mr. Denty was denied the job (he claimed) because of his age, Mr. Denty was working in Pennsylvania. The lawsuit was dismissed by the court because the job applied for was outside the U.S. ${ }^{\text {xix }}$

In Reyes-Gaona v. N. C. Growers Association, 250 F.3d 861 (4 ${ }^{\text {th }}$ Cir. 2001), Mr. Reyes-Gaona, a citizen of Mexico, applied (from Mexico) for a position with the N. C. Growers Association. He was rejected (he claimed) because he was over forty years old. The court dismissed the suit both because of Mr. Reyes-Gaona's citizenship and the location from which the worked was applied. ${ }^{\mathrm{xx}}$

Lastly, in Shekoyan v. Sibley, International, 409 F.3d 414 (D.C. Cir. 2005), Mr. Shekoyan, a legal immigrant residing in the U. S., was hired by an American firm to work in the Republic of Georgia. Mr. Shekoyan went to work, but his contract was subsequently not renewed because (Mr. Shekoyan claimed) of his national origin which caused co-worker conflicts on the job. The court again dismissed the lawsuit citing that Mr. Shekoyan was not a U.S. citizen and that the job in question was not in the U. S. ${ }^{\text {xxi }}$

\section{ETHICAL ISSUES FOR COUNSEL OF “AMERICAN-CONTROLLED” FIRMS}

An attorney for a U.S.-owned or controlled firm could simply advise overseas operations to ask about all citizenships of prospective employees and never hire an American. This directive would be ethically analogous to ordering a manager never to hire an applicant with an Hispanic surname in order to avoid potential violation of the Immigration Reform and Control Act.

Or perhaps ethical refuge could be found in a self-assurance that host country law adequately protects 
Americans working overseas. The author has previously published a paper reviewing sexual harassment laws in South-East Asia and Indo-China. Little or no protection was found. In act, in only Japan was prohibition and enforcement somewhat effective.

A more likely and ethically difficult issue would arise when American counsel discovered that local management having been made aware of the extraterritorial application of the U.S. Civil Rights Act, implemented policies to discover U.S. citizenship in its workforce and/or applicant pools, then proceeded to make sure that no U.S. citizen worked for the firm now or in the future.

The Model Code of Professional Responsibility, Canon 6, EC 6-4, DR 6-101 (A) (2) (1980), requires counsel to investigate possible misconduct of corporate officials. Further, the American Bar Association Committee on Ethics and Professional Responsibility has stated (opinion 1479, \{1981\}):

\{A\} lawyer should not undertake representation in disregard of facts suggesting that the representation might aid the client in perpetrating a fraud or otherwise committing a crime ... A lawyer must be satisfied, ... That he can perform the requested services without abetting fraudulent ... conduct and without relying on past client fraud to achieve results the client now wants.

Clearly, then, corporate counsel, upon discovering possible CRA violations by foreign operations, must inquire into the facts and circumstances in order to properly advise his client (top management) of the corporation's obligations and legal exposure for said misconduct. Too, counsel could take no part in furtherance of the misconduct (e.g. advising destruction of records).

Intentionally discharging American citizens or intentionally refusing to hire any American citizen constitutes "national origin" disparate treatment discrimination under Title VII. This is a far different case from corporate counsel learning, for instance, that the company intends to expand into Russia and, thus, in counsel's opinion, into economic disaster. In the latter, prudence of the decision might be challenged, but no intentional law violation is or has been committed.

When such illegal conduct has occurred or is contemplated, counsel must urge those in control over the conduct to reconsider their actions and in the event that those individuals refuse to alter their course, counsel must take the situation to the highest authority in the corporation (Model Rules of Professional Conduct 1.13). Model Rule 1.13(b) also provides that counsel might obtain a separate, independent legal opinion to confirm and reinforce counsel's presentation to the highest corporate authority.

Moreover, if taking the matter to the highest authority within the corporation fails to halt the illegal conduct Model Rule 1.13 further mandates that counsel take the ultimate step of exposing the matter to the Board of Directors. This, of course, implicates the Board members in the conduct (if they fail to correct it) and raises serious issues of their liability to stockholders and outsiders (see Geoffrey C. Hazard, Doing The Right Thing, 70 Wash. U.H.L.Q. 691 (1992)

When even this fails to halt the misconduct, American corporate counsel must decide whether to take the matter outside the corporation (e.g. government regulators) or whether counsel should resign. Both of these are beyond the scope of this paper, but the fact that the American Bar Association and the Model Rules of Professional Conduct contemplate them does indicate how serious the situation for counsel can become.

Clearly, those in charge of developing an ethics code will need to take into account certain "moral absolutism" situations, but will need to balance the "cultural relativism" values cited above both in terms of type of business they are in, as well as in the growing diversity of the work force. Having a code of ethics is important as it does show a concern for ethical issues and, if communicated well and enforced fairly at all levels of the business, it does guide behavior and can help shape the behaviors of those less prone to behave ethically. 
Features to be included in all codes of ethics include:

A) A clear and understandable written code. Oral, informal "codes" won't do.

B) A confidential, safe (to the worker) way to report suspected violations.

C) A way to get guidance as to what violates the code. It is here that the corporate attorney usually comes in. As most traditional corporate attorneys have been schooled in finance, taxation, employment law, etc., it is increasingly common in large concerns that a specialist attorney in ethics is hired for this work.

D) Clear communication of what is expected by the code of ethics in language suitable for laypeople, with demonstrations of appropriate/inappropriate conduct in tough areas.

E) At least on an annual basis, signed affirmations from all employees that their conduct has met the requirement of the ethics code for that year. It is a separate, serious, offense to lie on this form.

F) Fair, firm investigation and, ultimately punishment of violators, applied to all levels of employees in the firm. Investigations must protect both the accuser and the accused.

G) As a preemptive strike, all prospective employees should have their police records and employment histories checked. In May of 2006, McDonald's Restaurants in one city faced national embarrassment when it was disclosed that a sex offender with a long history of exploiting children, was hired as a manager of a McDonald's restaurant (employing many very young people). Then, when the employee's history was discovered, and he was terminated, he was hired by the national McDonald's training program to become a franchise manager!

\section{WHEN MAY AN ATTORNEY WITHDRAW FROM OR NOT ACCEPT A LEGAL ASSIGNMENT"?}

A code of ethics can help prevent ethical violations. Some violations may well, however occur and some of these might be so serious as to cause corporate counsel to consider extricating herself from the situation. Can the actions of a firm become so personally revolting that the attorney can no longer remain as counsel? The currently popular movie "The Constant Gardener" portrays a fictional (?) pharmaceutical company testing a medication on seriously ill people in Africa who have to sign a "consent" form for the trial treatment (the drug is unrelated to the illness of the people and is being tested at this stage solely for reactions, which turn out to be more serious than the illness that many of the victims had before they were "treated").

In this scenario, could corporate counsel who drafted the "consent form" withdraw from the representation? Reference to the Model Rules comes first. Rule 1.16(b) (4) governs withdrawal from employment. Rule 6.2(c) governs declining employment. The standard right to withdraw comes from, in civil suits, nonpayment of the attorney's bill. But, an attorney can also withdraw when there is a "fundamental disagreement" with a client's action. This can, of course, arise when a client continues to pursue a criminal course of conduct against the attorney's advice.

But, as it pertains to many ethical concerns of corporate attorneys, where the issue doesn't rise to commission of criminal acts or where criminality is speculative (the "Constant Gardener" situation), what can the attorney do? Revisions to Rule 1.16(b) (4) made in 2000 allow the attorney to withdraw when the client takes an action (or is ready to take an action) that the attorney views as personally "repugnant". Thus, the attorney is free to withdraw from representation for reasons totally unrelated to the legal aspects of the employment relationship.

For the attorney involved in a CRA matter, the conflict that may rise to "repugnant" might come from a strong belief that the CRA was enacted to give legal status to the anti-caste tradition in America's Declaration of Independence. Thus, a business action designed to avoid these obligations that would require legal input could well give rise to a "repugnant" situation. Conversely, another attorney might find ethical conflict in the feeling that Congress has no right burden private sector actions with moral obligations.

Some commentators have raised an additional ethical issue: "What justifies U.S. export of anti-discrimination law at all?"xxii Granted, the CRA is based upon some of America's core values. An individual is free to harbor religious racial, sexual, etc. biases, BUT when that personal belief is transferred into actions that violate others' rights (those core values of American society for instance, crushed by employment discrimination), that conduct will be punished. 
In an international ethics context, those who oppose extraterritorial enforcement of the CRA sometimes raise the argument that "discriminatory business is bad business". Essentially, the argument goes, the employer who discriminates in employment decisions will be less competitive. This author used to bring the point home to students in American classes by citing what professional baseball, etc. would have been had earlier racial prohibitions still been in place.

The above argument, however, assumes a relatively free market for the discriminated-against sector to find other outlets for their services. What if, for instance, the discriminated against group is denied education and/or experience required to do certain work (e.g. women not allowed to attend school beyond grade school)? Can the free market correct this?

\section{MAY COUNSEL TAKE REFUGE IN CONFLICTING INTERNATIONAL ETHICS?}

While, in the U. S., an old argument that CRA's violated a private person's right to "freedom of association" (thus not having to work alongside someone you don't want to work alongside) died a long time ago, the point may not be so clear in an international context. To many, "respect for cultural autonomy bears a close relation to the norms of tolerance and respect for difference that Title VII represents."

The CRA's have attacked such deeply ingrained discriminations in America as white supremacy, patriarchy and more currently, libertarian thought. Quoting from Kathy Robert's:

This background brings our questions sharply into focus: How can the United States ironically promulgate values with such a pedigree abroad? On what possible basis could remedial legislation such as this be extended beyond U.S. territorial borders?

On the other hand, why should U.S. companies be allowed to adopt the caste systems of the cultures where they invest if they do not have to? These are philosophical, ethical, and political questions. ${ }^{x i v}$

Thus, some would say the Western values of equality, etc. that are the core of the CRA's are universal. Therefore, forcing other cultures to adopt them if they wish to do business with us is fine. Others would claim that if Western cultures lead by example (enforcing the CRA's within their own countries and perhaps enforcing in limited form upon their own companies operating in another culture), other countries would see the wisdom of Western values and soon adopt them.

Maybe, though, these Western values have no "lock" on correctness. Often, the Western core values are linked to religious ideals, thus the "God" adopted by the country. Might the "God" of another country be correct?

Thus, a challenged attorney could declare that the ethical question at issue in an employment practice may well (thus ethically) be viewed from the perspective of the foreign culture. Farfetched? Not to Donald Fites, CEO of Caterpillar, who declared (when his firm was challenged for moving large numbers of operations and jobs overseas"), that it is not "realistic for 250 million Americans to control so much of the world's GNP." $x x v$

Mr. Fites may well be stating that his company has a higher loyalty to the welfare of workers all over the world rather than just to American workers. Might counsel, in deciding upon the ethical correctness of a foreign employment practice, simply change the word "loyalty" to the word "justice" -- or to the word "ethical"?

\section{SINCE THE COLONIAL SYSTEM IS LARGELY FINISHED, DO NOT OTHER COUNTRIES HAVE A RIGHT TO DEFINE ETHICS IN THEIR OWN TERMS?}

Clearly, resentment against former colonial masters is abundant in the world. When a foreign country sees the United States enforcing U. S. law in THEIR country, against business practices that arose in THEIR country, is this not colonialism returning? The CRA's, it is true, are enforced in the name of "The People of the United States of America", not in the name of Western values. Quoting the Roberts article again, "One need not look far to see how violently individuals and governments may defend cultural norms of subordination against economic interventions 
that threaten to destabilize their power. ${ }^{\text {xxi }}$

Perhaps this brings us full circle. Does the issue posited here simply come back to the two leading legal, thus ethical, questions courts are debating in the "Recent Cases" section of this paper:

1. What is the proper scope and definition of "covered employee"? Would restricting extraterritorial enforcement only to citizens of the U. S. ease most of the international concerns raised in this paper?; and

2. What is the extent to which extraterritorial enforcement should be allowed against firms that are not operating under the American corporate name? Maybe this opens the door to foreign subsidiaries being set up under names not easily tied to the American parent, but that could be a matter of U. S. enforcement also.

\section{CONCLUSION}

Ethical confrontations for counsel involved in any extraterritorial business decision brings to light many factors of first impression. This paper has utilized the rather easy-to-understand Civil Rights Acts (1964 and 1991 ) issues that present themselves.

Should the American Bar Association move now to adopt ethical standards as guidance for counsel? If so, in adopting the ethical standards, will the drafters find themselves faced with the same issues this paper posits for practitioners/

Clearly, some effort must be made to provide attorneys with ethical guidance and the world's business community with some standards for international business conduct.

i 42 U.S.C. $2000 \mathrm{e}$

ii 42 U.S.C. 1211

iii Equal Employment Opportunity Commission, Enforcement Guidance on Application of Title VII and ADA to American Firms Overseas, Notice 915.005, p. 2313 (1998).

iv Bourselan v. Arabian American Oil Company, 653 F. Supp. 629, Texas (1987).

$\checkmark$ Ibid., 499 U.S. 244 (1991)

vi 42 U.S.C. 1211

vii Ibid.

viii Fernandez v. Wynn Oil Co., 653 F. 2d 1273 (1981)

ix Meritor Savings Bank v. Vinson, 40 FEP 1822 (1986)

$x$ Ibid., Note 3

xi Ibid., Note 2

xii Ibid., Note 3

xiii Mahoney v. RFE/RL, Inc., 818 F. Supp. 1 (D.D.C. 1992)

xiv Ibid.

xv Ibid., Note 8

xvi Ibid., Note 3

xvii Hazard, G. C., Doing The Right Thing, 70 Wash. U. H. L. Q., 691, 699

xviii Ibid., at 697

xix Denty v. SmithKline Beecham Corp., 109 F.3d 147 (3d Cir. 1997)

xx Reyes-Gaonav. North Carolina Growers Assoc., 250 F.3d 861 ( $4^{\text {th }}$ Cir. 2001)

xxi Shekoyan v. Sibley International, 409 F.3d 414 (D.C. Cir. 2005)

xxii Roberts, Kathy, "Correcting Culture: Extraterritoriality and U.S. Employment Discrimination Law", Hofstra Labor \& Employment Law Journal, Vol. 24, 295, 319

xxiii Ibid., p. 321

xxiv Ibid.

xxv Ibid., p.322

xxvi Ibid., p. 330 


\section{NOTES}

